\title{
PERSISTENCE IN LABOR SUPPLY AND THE RESPONSE TO THE SOCIAL SECURITY EARNINGS TEST
}

\author{
Leora Friedberg and Anthony Webb*
}

CRR WP 2006-27

Released: December 2006

Draft Submitted: October 2006

\author{
Center for Retirement Research at Boston College \\ 258 Hammond Street \\ Chestnut Hill, MA 02467 \\ Tel: 617-552-1762 Fax: 617-552-0191 \\ http://www.bc.edu/crr
}

\begin{abstract}
* Leora Friedberg is an economics professor at the University of Virginia. Anthony Webb is a research economist at the Center for Retirement Research at Boston College. The research reported herein was performed pursuant to a grant from the U.S. Social Security Administration (SSA) funded as part of the Retirement Research Consortium. The findings and conclusions are solely those of the authors and do not represent the views of SSA, any agency of the Federal Government, the University of Virginia, or Boston College.

(C) 2006, by Leora Friedberg and Anthony Webb. All rights reserved. Short sections of text, not to exceed two paragraphs, may be quoted without explicit permission provided that full credit, including (C) notice, is given to the source.
\end{abstract}




\section{About the Center for Retirement Research}

The Center for Retirement Research at Boston College, part of a consortium that includes parallel centers at the University of Michigan and the National Bureau of Economic Research, was established in 1998 through a grant from the Social Security Administration. The Center's mission is to produce first-class research and forge a strong link between the academic community and decision makers in the public and private sectors around an issue of critical importance to the nation's future. To achieve this mission, the Center sponsors a wide variety of research projects, transmits new findings to a broad audience, trains new scholars, and broadens access to valuable data sources.

\section{Center for Retirement Research at Boston College}

258 Hammond Street

Chestnut Hill, MA 02467

phone: 617-552-1762 fax: 617-552-0191

e-mail: crr@bc.edu

www.bc.edu/crr

Affiliated Institutions:

American Enterprise Institute

The Brookings Institution

Center for Strategic and International Studies

Massachusetts Institute of Technology

Syracuse University

Urban Institute 


\begin{abstract}
This paper investigates the impact on labor supply of changes in the Social Security earnings test in 1996 and 2000. We highlight how the persistence of labor supply choices influences both responses to policy changes and the estimation of such responses. We do this in two ways. First, we use data from the Health and Retirement Study and the Current Population Survey that allows us to compare employment transitions across cohorts that are differentially affected by changes in the earnings test rules. We show that conditioning on last year's employment status is important in identifying responses to current earnings test changes. Second, we test the effect of not only current but also anticipated as well as past earnings test parameters which cohorts faced at earlier ages. We find that past and anticipated future rules influence current employment and earnings. Our results help to identify an effect of earnings test changes affecting ages 65-69 on employment at younger and older ages, which suggests caution about the use of neighboring age groups as control groups in analyzing responses to the earnings test. We also show that earnings test changes that were initiated in 1996 had an important effect, in addition to the changes in 2000 that have been extensively studied.
\end{abstract}




\section{INTRODUCTION}

Previous research showed that the Social Security earnings test has had a substantial effect on hours choices among older people who continue to work. However, the role of the earnings test in influencing retirement remains unclear. In theory, the earnings test will only affect retirement if labor supply is constrained in some way that influences dynamic choices, and the importance of such constraints remains a topic of investigation. Earlier structural models found little evidence of an effect on retirement, but that result may have been sensitive to the assumptions made in modeling labor supply constraints. Reduced-form studies have found significant effects when studying recent earnings test rule changes.

Recent changes in the earnings test rules, combined with the availability of longitudinal data sets, offer an opportunity to investigate these issues. While other recent studies have found significant effects of the elimination of the earnings test in 2000, we argue that some effects are missed by ignoring 1996, and we focus on the importance of recognizing inertia in labor supply. By using data on labor supply transitions and by testing for effects of not only current but also past earnings test parameters which cohorts faced, we can identify the persistence of labor supply choices and extend recent research on the earnings test. We show that conditioning on last year's labor force status is important in identifying responses to earnings test changes in the current year. We also find that past and anticipated future earnings test rules affect current labor supply. While we focus on rules that were in place at ages 62 and 65, when many people make retirement decisions, these insights can be generalized in a more formal model of labor supply to capture dynamic effects across a broad age range.

This research has growing relevance in light of recent trends in retirement. Following decades of decline, the average retirement age stabilized in the 1980s at around 62 and has started to rise more recently. ${ }^{1}$ The delays in retirement mean that growing numbers of workers are confronting the earnings test, so interactions between the earnings test and constraints on labor supply are taking on more importance. Lastly, this research highlights how inertia in labor supply choices influences the response to policy changes more generally. That in turn raises

\footnotetext{
1 Our tabulations of data from the March CPS show that the employment rate of people aged 62 rose from $41.3 \%$ in $1992-94$ to $48.4 \%$ in $2003-05$.
} 
concerns about estimation methods that assume an instantaneous response when studying policy changes.

The rest of this paper is organized as follows. In Section II, we discuss the earnings test rules along with theoretical predictions and past empirical analysis of the impact on labor supply. In Section III we describe the data and in Section IV the results from our analysis of the Current Population Survey and the Health and Retirement Study. We conclude in Section V.

\section{BACKGROUND}

In this section, we discuss the earnings test rules along with theoretical predictions and past empirical analysis of the impact on labor supply. We distinguish between predictions when labor supply can be freely chosen or else is subject to constraints that influence the response to the earnings test, and we discuss the degree to which previous studies recognize such constraints.

\section{A. The Social Security earnings test}

The impact of current earnings on benefits.

Social Security beneficiaries who earn too much at particular ages suffer a reduction in their Social Security benefits. Beneficiaries between ages 62 and about 64 in 2005 lost \$1 in benefits for every $\$ 2$ in earnings above an annual threshold of $\$ 12,000$. The rules at ages 62-64 have been stable since the 1970s, with the earnings threshold increasing with the rate of annual wage inflation.

In contrast, the rules faced at ages 65-69 have undergone substantial changes in recent years, as highlighted in Table $1 .^{2}$ Beginning in 1978, the earnings test threshold was about $1 / 3$ higher than it was for ages 62-64. In 1990, the benefit reduction rate for ages 65-69 was lowered from 50\% to 33\% for earnings above the threshold. 1996 legislation raised the threshold in stages. It jumped from $\$ 11,280$ in 1995 to $\$ 12,500$ in 1996; rose in annual increments of $\$ 1000$ until reaching \$15,500 in 1999; and then was scheduled to hit \$17,000 in 2000, \$25,000 in 2001, and $\$ 30,000$ in 2002. In 2000, a new law eliminated the earnings test above the Full Retirement Age (FRA). Lastly, while the FRA used to be 65, it began rising gradually to 66 in 2000 due to much earlier legislation. The high earnings thresholds set in 1996 now apply in the calendar year

\footnotetext{
${ }^{2}$ A series of earlier laws culminating in 1983 eliminated the earnings test at ages 70 and above.
} 
during which someone reaches the FRA. Those covered by this last provision lost $\$ 1$ in benefits for every \$3 in earnings above \$31,800 in 2005.

\section{Identification of earnings test effects in our analysis.}

In this paper, we emphasize that recent rule changes generated shocks to anticipated values of the earnings test threshold, and those shocks varied substantially across cohorts. This variation, as shown in Table 2, is richer than recent studies have recognized. Panel A of Table 2 shows the value of the earnings test threshold by year and age for cohorts born between 1928 and 1940. Panel B shows the values that would have been anticipated by the same cohorts at age 62; we assume that they correctly forecasted the rate of wage inflation (and thus the normal growth in the annual value of the threshold), but not the legislation of 1996 and $2000 .^{3}$

This perspective reveals several interesting features. Other recent studies have focused entirely on the 2000 elimination of the earnings test, but the 1996 jump in scheduled threshold values generated sizeable shocks to earnings test rules. Moreover, those shocks are confounded with the 2000 change. Earlier studies simply compared labor supply changes before and after 2000 to identify effects of the earnings test. Yet, the elimination in 2000 should be considered against a baseline in which the earnings test threshold had risen for several years and would have hit \$17,000 in 2000, \$25,000 in 2001, and \$30,000 in 2002 - considerable amounts for people still working above the age of $65 .{ }^{4}$

In considering both changes together, we can see that the range of variation in anticipated earnings test rules stretches across numerous cohorts. The timing of shocks to earnings test parameters is indicated by shading in Table 2. In shaded cohort-year cells, threshold values rose some time after the cohort reached the age of 62 . The first to experience such a shock was the 1927 birth cohort, which turned 69 in 1996 and saw a small jump in the threshold in their last year facing the earnings test. The last was the 1937 birth cohort, which turned 62 in 1999 and was surprised by the elimination of the earnings test a year later.

\footnotetext{
${ }^{3}$ It is reasonable to believe that the law changes were not anticipated in earlier years. The 1996 and 2000 laws were enacted, respectively, on March 29 and on April 7, and both were made retroactive to January 1. The 1996 law was not discussed in policy circles in the prior year. The Economic Report of the President of February 1999 discussed distortionary effects of the earnings test, but there was little media attention until bipartisan legislation was proposed in early 2000.

${ }^{4}$ According to our tabulations using the March CPS of 1992-2005, \$30,000 slightly exceeds median nominal annual earnings - $\$ 29,000$ - of people aged 58-61 who worked the entire year and exceeds the $75^{\text {th }}$ percentile value for people aged 66-69 who worked at all.
} 
The magnitude of the shocks is summarized in Panel C. Panel C reports the discounted present value of actual and of anticipated threshold values, from an age-62 perspective, summed up over ages 62-69. ${ }^{5}$ To understand these calculations, note that the present values are the same for the final cohorts in Table 2; they reached age 62 after 2000 and were not surprised by any changes in threshold values.

The anticipated and actual present values of the thresholds diverge for birth cohorts 19271937. The divergence is small for early cohorts, which experienced changes in threshold values as they neared age 70. The gap jumps for the 1931 cohort. They turned 62 in 1993 and would have expected an earnings test threshold of about \$11,400 at age 65 in 1996 and \$13,900 at age 69 in 2000; this results in an anticipated present value of \$75,323, summed up at age 62 . The threshold at age 65 was in fact $\$ 12,500$, rose each subsequent year, and then disappeared at age 69, yielding an actual present value at 62 of $\$ 101,576$, about 1/3 higher. The gulf reaches a maximum for the 1934 cohort, which experienced an anticipated present value of \$109,918 and an actual present value of $\$ 170,404$. The gap narrows afterwards but remains notable through to the final shock experienced by the 1937 cohort.

Our regressions will analyze how labor supply was affected by current but also by anticipated future parameters. Anticipated rules can matter if labor supply choices have longlasting consequences, for reasons that we review shortly. Moreover, if labor supply exhibits inertia, then current labor supply can also reflect the influence of earlier earnings test rules, so we include contemporaneous and anticipated parameters that were in place at younger ages as well. While our analysis is obviously reduced-form, since we estimate the effect of policy parameters but not a fully specified model of labor supply, the use of past and future policy parameters can nevertheless identify the presence of important dynamic effects.

\section{The deferral of benefits.}

Before we discuss the theoretical effects of the earnings test, we take note of additional rules that govern the relationship between the earnings test and future Social Security benefits. Just as future benefits are raised for people who delay claiming Social Security in the first place, they are compensated with higher future benefits for each month's worth of benefits lost to the

\footnotetext{
${ }^{5}$ In making these comparisons, it is important to avoid confusing the absence of the earnings test (and hence of an earnings threshold) with the presence of the earnings test and a threshold of $\$ 0$. In Table 4, we impute a value for the threshold of $\$ 50,000$ to represent the absence of the earnings test after 1999 . In our regression analysis, we instead attribute a value of 0 in those cases, while adding a dummy variable for the earnings test being in place.
} 
earnings test. Before the FRA, the actuarial adjustment raises future benefits by about $7 \%$ for each year's worth of lost benefits. Over the FRA, the Delayed Retirement Credit, which does the same, has risen gradually from 3\% in 1990 and will reach $8 \%$ in $2008 .{ }^{6}$ A 7-8\% credit is actuarially fair on average, so someone with average life expectancy and no borrowing constraints should be indifferent about the timing of benefit receipt.

These credits undermine the long-run fiscal gains from the earnings test and should reduce the impact of the earnings test on labor supply. Many beneficiaries appear to react to the earnings test, nonetheless, probably because the credits are not well understood. The earnings test's impact is confirmed by the clustering of beneficiaries who keep their earnings right around the threshold value, as demonstrated in numerous papers mentioned later. Articles in Money and the Los Angeles Times describing the earnings test failed to note that future benefits are raised if current benefits are reduced. ${ }^{7}$ Similarly, Reimers and Honig $(1993,1996)$ found no evidence of increased labor force re-entry when the Delayed Retirement Credit was raised. Consequently, we ignore their effects, as have most other researchers.

\section{B. Theoretical predictions}

In this subsection, we discuss predicted effects of the earnings test on labor supply under a variety of assumptions about the flexibility of labor supply choices.

\section{Unconstrained labor supply.}

Figure 1 shows the piecewise linear budget constraint generated by the earnings test, while abstracting from other taxes for simplicity. Implicit in Figure 1 are two important assumptions: the first, which we just discussed and maintain throughout our analysis, is that people view the earnings test as a tax rather than an actuarially fair deferral of benefits; and the second is that people can choose to work any number of hours at their going wage. The resulting budget constraint has a convex kink at the earnings test threshold and a nonconvex kink when benefits are exhausted after passing the threshold.

The jump in the earnings test tax rate from 0 to $33-50 \%$ at the threshold is large in absolute terms and in comparison to most of the rest of the government tax and transfer system.

\footnotetext{
${ }^{6}$ The DRC has been raised by a half percent every year since 1990 and reached $7 \%$ in 2005.

${ }^{7}$ Simon (1996), Kristof (1997). Coile, et al, (1999) found that many beneficiaries for whom the adjustment is actuarially fair or better claim benefits early at age 62, suggesting that the credits are not fully taken into account in the claiming decision either.
} 
Yet, the impact of the earnings test on labor supply is ambiguous, depending on where someone would locate on the budget constraint in its absence. Beneficiaries with earnings below the threshold experience no change in incentives and hence in labor supply due to the earnings test. For beneficiaries with somewhat higher earnings, the earnings test induces a substitution effect from facing the tax rate, leading to lower hours, and an income effect from the loss of benefits, leading to greater hours. The substitution effect will induce some beneficiaries to reduce earnings just to the convex kink at the earnings threshold. Lastly, beneficiaries with high enough earnings will face only an income effect from the loss of benefits and will work more.

The ambiguity of most of the labor supply predictions makes it difficult to obtain evidence about the earnings test using standard OLS or IV methods. As alternatives, many researchers resort to nonparametric analysis of how people locate along the budget constraint and especially at the convex kink, while a few others have estimated structural models of labor supply.

\section{Constraints on static labor supply.}

Considerable evidence suggests that workers face constraints on their labor supply choices. Such constraints include the concentration of work schedules at 40 hours per week, lower wages that are offered in part-time jobs compared to full-time jobs, and government regulation of overtime work and of the provision of fringe benefits to full-time workers. ${ }^{8}$ Thus, parts of the budget constraint with low hours of work may be either dominated by fixed costs that workers face or unavailable due to fixed costs that employers face. Other parts of the budget constraint may consist of points that offer discrete bundles of wages and hours.

The effects of the earnings test will be altered if the budget constraint is limited by these factors. Imposing the earnings test will cause fewer people to adjust their labor supply, along with greater responses by those who do adjust. One unambiguous prediction distinguishes this model from the earlier one: the earnings test will now lead some people to retire, as long as nonparticipation dominates some discontinuous points on the budget constraint.

\footnotetext{
${ }^{8}$ A very incomplete summary of this evidence includes Card (1990) on tied wage-hours contracts; Altonji and Paxson (1988) on wage cuts associated with transitions to part-time work; and Cogan (1981) and Hausman (1980) on fixed costs of work. The relevance of such constraints in affecting retirement are summarized by Hurd (1996).
} 


\section{Constraints on labor supply transitions.}

In addition, some constraints may cause labor supply choices to be persistent over time. It is likely that there are fixed costs of changing jobs and even changing work hours within a job, as search, hiring, and training are costly to workers and employers. These costs may be exacerbated by the static constraints described above; for example, the difficulty of finding a job offering the particular wage-hours combination that a worker prefers may increase job search costs.

Such fixed costs will introduce inertia into labor supply decisions, with amplified effects for older workers who have shortened time horizons due to impending retirement. Even a worker who intends to postpone retirement indefinitely may find it difficult to credibly signal this intent to potential employers. Transition costs are probably even greater for people who seek to return to work after retiring and whose skills may be eroded or outdated.

For these reasons, we expect a much smaller immediate response to earnings test changes from people who are not working, given the difficulty of returning to the labor force. Even among those in jobs, we expect a muted impact early on. We expect to see a greater response as younger workers with time to adjust their plans age into the new rules.

The persistence of labor supply choices can also cause changes in labor supply at other ages not directly affected by a change in the earnings test. Knowing that the earnings test now disappears at the FRA instead of at 70, people in their early 60s might postpone retirement in order to take advantage of the higher return from working in their late 60s. They would do so if the gain from returning to the labor force after retirement in order to work after the FRA is dominated by the gain from staying in their jobs in the interim. Similarly, people who are now induced to continue working in their late 60s may stay in the labor force into their 70s, while before they would not return to the labor force upon reaching 70 .

These considerations expand the range over which the earnings test may affect labor supply but also create empirical difficulties. A common strategy in the recent literature is quasiexperimental estimation that uses slightly younger and older workers as control groups to 
difference out other trends in labor supply affecting the treatment group over the same period. These hypothesized spillover effects of the earnings test undermine that strategy. ${ }^{9}$

\section{Empirical literature}

The empirical approaches taken in studies of the earnings test can be divided into three basic types - non-parametric analysis generally focused on bunching at the earnings test kink, reduced-form regressions of labor supply on earnings test parameters, and estimation of structural labor supply models. The papers also differ in the data and time periods that they study. A careful analysis of these differences can help explain the mixed results from this literature.

\section{Bunching at the earnings threshold.}

Many papers have demonstrated that workers cluster at the earnings test threshold (Vroman 1985, Burtless and Moffitt 1985; Friedberg 1998, 2000; Gruber and Orszag 2003; Haider and Loughran 2006; Manchester and Song 2006). Friedberg (2000) showed that bunching at the earnings threshold is statistically significant and shifted significantly when earnings test rules changed. Clusters of beneficiaries appeared at the new higher threshold after it was raised in 1978 for ages 65-71, and disappeared after the earnings test was eliminated in 1983 for ages 70-71. While most studies used self-reported data, Haider and Loughran showed that even more bunching is evident when using accurate administrative data on earnings. Manchester and Song estimated quantile regressions, focusing on differential responses along the earnings distribution to the elimination of the earnings test in 2000. They found significant increases in earnings concentrated over a region of the earnings distribution that corresponded to the kink and somewhat above, and significant decreases over a region below.

The magnitude of bunching at the kink in the budget constraint makes it clear that older workers enjoy some degree of flexibility in their labor supply choices. Ruhm (1990) documented the prevalence of switches into "bridge jobs" after exits from career jobs. Also, older workers are much more likely to work part-time. ${ }^{10}$ Thus, the importance for older workers

\footnotetext{
${ }^{9}$ The earnings test may also affect younger workers through life cycle labor supply effects. Under this model, reducing the tax at older ages would lead to a shift in labor supply from younger to older ages; but given our focus on constraints on labor supply choices, we do not think that this type of intertemporal shifting is likely to dominate. ${ }^{10} 49.2 \%$ of $65-69$ year olds working in the 1990s worked usual part-time hours (less than 35 per week), compared to $14.2 \%$ of 50-59 year old men. These statistics are computed using supplemental weights for all men who worked last year in the March CPS from 1992 to 2000.
} 
of limits on part-time work, difficulties in switching jobs, and other constraints remains an open question.

The appeal of studying bunching lie in its simplicity. It provides a straightforward test that the earnings test has an impact, since it does not require making inferences about where workers would otherwise locate on the budget constraint in the absence of the earnings test. ${ }^{11}$ The limitation of such analysis, though, is that, without a model, it provides very limited information about responses to other possible changes in the earnings test. While Saez (2005) shows how to infer the local compensated substitution elasticity from the magnitude of bunching at a convex kink, that approach does not identify the income elasticity, and its use has not been extended to cases where the budget constraint is discontinuous due to the types of constraints outlined earlier.

\section{Reduced-form analysis of labor supply.}

Another approach has been to estimate average labor supply responses to earnings test parameters, with the goal of analyzing aggregate responses and/or avoiding assumptions required to specify a model of labor supply. Recent studies have investigated the elimination of the earnings test at ages 65-69 in 2000, and several have analyzed changes that occurred in 1990 and earlier, but none have examined the increase in the earnings threshold that began in 1996.

These reduced-form studies estimated how work and earnings relate to earnings test parameters (Gruber and Orszag 2003) or dummies for the earnings test being in place (Haider and Loughran 2006, Manchester and Song 2006, Tran 2005). ${ }^{12}$ This estimation approach cannot separately identify conflicting income and substitution effects on hours of work, though, which again leaves us unable to extrapolate from the estimates to other possible changes in the earnings test.

This approach can be used to test one unambiguous prediction noted above - the earnings test may induce people to retire if labor supply is constrained in some way. Manchester-Song, Tran, and Haider-Loughran all show that employment at ages 65-69 increased after the 2000

\footnotetext{
${ }^{11}$ Testing the related prediction that people should avoid the nonconvex kink in the budget constraint is difficult because its location is difficult to measure for households with dependent benefits and for age-eligible workers who are not receiving benefits.

${ }^{12}$ Gruber-Orszag and Manchester-Song also showed that Social Security benefit claiming rose when earnings test rules were relaxed. These results confirm that many people view the earnings test as a tax; otherwise claiming and labor supply decisions would be de-linked if benefit deferrals (due to delayed claiming or due to the earnings test) were perceived as actuarially fair.
} 
elimination of the earnings test. Moreover, they show that this effect was stronger among those already in the labor force and increased in magnitude over time, so constraints that generate persistence in labor supply choices appear to be important. ${ }^{13}$ The first part of our empirical analysis builds on this approach by using different data sets and more post-2000 data, through 2005, and, importantly, by looking at the 1996 as well as the 2000 change. ${ }^{14}$ The second part of our analysis investigates responses to not only current but also past and anticipated future earnings test rules.

\section{Estimation of labor supply models.}

A structural model formally captures the impact of the earnings test on after-tax wages and income and hence on labor supply. As an example, Friedberg (2000) estimated a truncated maximum-likelihood model of the choice of work hours among workers, using a sample of repeated cross-sections covering time periods before and after changes in the earnings test rules. Burtless and Moffitt (1985), Gustman and Steinmeier (1986), Berkovec and Stern (1991), and Rust and Phelan (1997) used longitudinal data to estimate structural retirement models, allowing for distinct wages for full-time versus part-time work. Burtless and Moffitt treated the earnings test as a pure tax, while Gustman and Steinmeier incorporated the deferral of benefits. They estimated small effects of the earnings test on labor supply. This may be a consequence of estimating a full model of retirement, which inevitably focuses more attention on finding parameter values to explain the large numbers who retire than on the relatively smaller numbers who continue to work and face the earnings test. It may also arise from modeling the budget constraint in this fashion, since it requires simplifying the budget constraint to a full-time and a part-time wage-hours bundle, and also imputing those bundles.

Structural models are attractive in providing coherent predictions about responses to earnings test changes and about labor supply parameters more broadly. However, they may face difficulties in capturing heterogeneity in the types of restrictions that people face in their labor

\footnotetext{
${ }^{13}$ Gruber-Orszag and Haider-Loughran found no change in employment following the 1983 elimination of the earnings test for ages 70-71, in contrast to the results for 2000. Haider-Loughran employed the same data and methods to look at both changes; they speculated that the older age of those affected in 1983 limited their response, and they showed a diminishing response by age in 2000 .

${ }^{14}$ Our data extends the analysis of others by another 2-3 years. Manchester-Song and Haider-Loughran had the advantage of accurate information on earnings, benefits, and birthdays from administrative panel data. Our data from the HRS also includes administrative records on earnings. They could not observe hours of work in their data, and so distinguish the contribution of hours choices to earnings. While Haider-Loughran also used survey data that was matched to administrative records, those data sets from the late 1970s and early 1980s are quite old.
} 
supply choices. Therefore, there is some appeal in reduced-form studies that can reveal the impact of such constraints without having to make a choice about how to model them explicitly.

\section{DATA}

We use two data sources that report employment transitions and cover a period from before 1996 until after 2000. The longitudinal Health and Retirement Study (HRS) was not used in earlier studies of the earnings test, while the March Current Population Survey (CPS) has not been used to analyze employment transitions as we do here.

\section{Current Population Survey.}

We use the March CPS to focus on employment and single-year transitions in employment. The CPS is a nationally representative survey of employment status covering well over 100,000 individuals per month. The March supplement to the CPS reports information for the previous year's sources of income (allowing us to determine an individual's earlier location on the budget constraint generated by the earnings test) and labor supply (allowing us to analyze labor force transitions into and out of work and across employers). ${ }^{15}$

We select everyone in the CPS aged 55-74 between the years of 1992 and 2005 . Our sample consists of, on average, about 1,000 people per age per year until 2001 and 1,500 after that. In all of our analysis, we use survey weights so that our statistics are nationally representative. ${ }^{16}$ We can only identify age in March, and not birthdays, so our knowledge of each respondent's earnings test parameters at transitional ages is imprecise. We define as those working last year anyone who worked at least one week. We define as those working now anyone who reports being at work or in a job but absent from work during the survey week.

Statistics on employment and earnings for the sample are shown in Table 3. Employment rates rise through the period, but the timing differs across age groups, with greater gains during the 1990s for ages 55-61, throughout the period for ages 62-64, and in the 2000s for ages 65-69.

\footnotetext{
15 Tran (2005) matched across monthly CPSs to generate a series of one-year panels, but doing so induces attrition bias that our use of the CPS avoids. Households are in the CPS for four consecutive months in two consecutive years. However, the CPS interviews households at the same address rather than the same households across months. Since moving out of jobs is correlated with moving out of one's house, matching will undercount labor supply transitions and generate attrition bias.

${ }^{16}$ We use the CPS basic weights and apply the adjustment factors developed by Povlika and Miller (1998) for pre1994 weights. Stewart $(2002,2005)$ recommends this procedure when combining retrospective and current data in the March surveys across this time period, as we do, because the 1994 redesign of the CPS had a small effect on the coding of employment and unemployment.
} 
Health and Retirement Study.

The HRS can be used to follow employment transitions as cohorts aged through the late 1990s and early 2000s. The HRS is an extremely detailed, longitudinal, nationally representative survey of older Americans that is conducted every two years. It is smaller than the CPS but collects very detailed information on labor supply and income. Its primary disadvantages relative to the CPS is the smaller sample size and the absence of the full age ranges of people who might be affected by the earnings test.

The main cohort of interest is the Original HRS cohort. That group consists of 12,521 individuals aged or married to someone aged 51-61 in 1992, and thus aged 59-69 in 2000. In order to analyze people aged 58-74 in every year from 1992 on, we also add information from other cohorts. The AHEAD (Assets and Health Dynamics of the Oldest Old) cohort began in 1993 and was aged 70 and older in 1992. The CODA (Children of the Depression) cohort entered in 1998 when they were aged 68-75 and hence were aged 62-69 in 1992, at the beginning of the period we examine. The WB (War Babies) cohort also entered in 1998 when they were aged 51-56 and hence were aged 57-62 in 2004, at the end of the period we examine.

Respondents in the HRS were asked to consent to having their records linked to data on earnings reported to the Social Security Administration. ${ }^{17}$ We used retrospective earnings data from 2004 back to determine annual employment status, although this will miss workers in noncovered jobs, primarily those working in some state and local governments. The 2004 data is preliminary and has not been completely cleaned by the HRS staff, so our conclusions based on HRS data should be regarded as tentative.

\section{EMPIRICAL RESULTS}

We begin by showing graphs of work, full-time work, and earnings by age group and year preceding and following the 1996 and 2000 earnings test changes. It can be difficult, though, to visually distinguish aggregate labor supply patterns from responses to the earnings test, so we then employ a regression framework to identify shifts in labor supply that coincide

\footnotetext{
${ }^{17}$ Given that some respondents did not consent, Gustman and Steinmeier (1999) examine associated sample selection issues. The matching rate in 1992 was $71.6 \%$. While they found that some observable variables like race, wealth, and education have statistically significant effects on matching, they explain very little of the overall observation.
} 
with and follow changes in earnings test parameters. We begin the analysis in 1992, which provides a few years to identify labor supply patterns before the 1996 change. The analysis ends in 2003-2005, depending on the data set and the outcome variable that we focus on.

\section{A. Graphical analysis}

\section{Work and non-work.}

We use the CPS to observe one-year labor supply transitions for large samples. This approach demonstrates the persistence of labor supply choices. The panels of Figure 2 show employment rates for age groups from the late 50s to early 70s between 1993 and 2005. The stock of people working in jobs appears in Figure 2-A, while the flows into work by those working and not working in the previous year appear in Figures 2-B and 2-C.

These flows reveal two general features. First, the majority of people working in a given year continue to work in the next year, according to in Figure 2-B. The survival rate in work diminishes by age but remains at over 2/3 even for ages 70-74. Second, very few people return to work in Figure 2-C after not working at all in the previous year. The hazard rate into work is always under $5 \%$ and diminishes by age. ${ }^{18}$

Next, we show that work flows reveal more about the earnings test than does the stock of employment. In Figure 2-A, we see small blips upward in the employment rate at ages 66-69 in 1996 and 2000, but employment increased gradually over this period for workers at all ages from 55 and up. ${ }^{19}$ The flows in Figures 2-B and 2-C reveal clearer responses.

At ages 66-69, the flows continuing to work and returning to work both rise in 2000, while the flow continuing to work rises in 1996 as well. In Figure 2-C, the jump in the flow returning to work, while statistically significant, subsided after a single year. This back-to-work rate almost doubled from slightly under $1 \%$ in the late 1990 s to $1.7 \%$ in 2000 , but it accounted for less than one-fifth of the overall gain in the employment rate in 2000, compared to the late 1990s average. Moreover, the immediate drop back to earlier rates suggests that slightly younger workers promptly adjusted their exit decisions.

Meanwhile, the percentage staying in a job at ages 66-69 in Figure 3-B rose from 73-75\% in the early 1990s to $77.3 \%$ in 1997, then dropped a little, and then rose to $78.1 \%$ in 2000 and

\footnotetext{
18 It is clear from the HRS that people are more likely to return to work after absences that are shorter than one year. 19 When we look at age groups in the March CPS, we avoid at this point including people aged 65, since we do not when they turned 65 or when they reached the FRA in some years.
} 
peaked at $81.2 \%$ in 2004 . Also interesting are the gains in the percentage of slightly older and younger workers, aged 62-64 and 70-74, staying in jobs after 1996 and 2000. The increase for older workers appeared with a lag. These effects suggest that these groups also respond to the earnings test, even though they were not directly subject to the rule changes.

Next, we will decompose these gains by full and part-time work and along different parts of the earnings distribution. After that, we will use regression analysis to help sort out underlying shifts in labor supply from those that coincide with and follow the earnings test legislation.

\section{Full and part-time work.}

Figures 3-A and 3-B show the percentage of people working full and part-time last week, among people who worked last year. We expect different responses since working full-time often subjects someone to the earnings test. Conditioning the sample on working last year focuses on those who are most responsive to rule changes, as we have shown.

The graphs suggest that people responded to the earnings test changes by staying longer in full-time work, as predicted. The percent working full-time at ages 66-69, among those working last year in Figure 3-A, rose a little after 1996 and rose by more, and in a gradual fashion, after 2000. Looking at part-time work in Figure 3-B, there was no apparent change after 1996, so the gain at that point in full-time work among those working last year was fed by a drop in retirement. In contrast, part-time work rates declined after 2000, contributing to the increase in full-time work. As we saw with employment, full-time work rates also rose for slightly older and younger workers not directly affected by the rule changes.

\section{Annual earnings.}

As we discussed earlier, raising or removing the earnings test threshold should have differing effects on earnings and hours of work, depending on how much someone was initially earning. We look for evidence of these differences by adapting the approach of Manchester and Song (2006), who examined how quantiles of the earnings distribution of workers shifted before and after 2000. They found that earnings between roughly the $30^{\text {th }}$ and $40^{\text {th }}$ percentiles declined somewhat, and earnings between the $60^{\text {th }}$ and $80^{\text {th }}$ percentiles rose a great deal. The latter values are in the vicinity of the earnings test threshold values before 2000 . 
In order to look for differing responses, we analyze data from the CPS on last year's earnings. We compute percentile values of real earnings (measured in 2005 dollars) ${ }^{20}$ for workers by age group and year, and we track these percentile values over time. We focus on earnings between the $30^{\text {th }}$ and $40^{\text {th }}$ percentiles and between the $60^{\text {th }}$ and $80^{\text {th }}$ percentiles. ${ }^{21}$

Figure 4-A reports average real earnings between the $30^{\text {th }}$ and $40^{\text {th }}$ percentiles by age group and year, and Figure 4-B reports the same for the $60^{\text {th }}$ and $80^{\text {th }}$ percentiles. In Figure 4-A there is little change in real earnings in the $30^{\text {th }}-40^{\text {th }}$ percentile range, associated with either the 1996 or 2000 rule changes. This may occur because our data set is relatively small and our measure of earnings less accurate, compared to the data that Manchester and Song use. However, in Figure 4-B real earnings at the $60^{\text {th }}-80^{\text {th }}$ percentiles rose following the 1996 and 2000 changes. Interestingly, the gain is somewhat greater for 1996, which Manchester and Song do not study.

\section{B. Summary regressions}

\section{Empirical approach.}

At this point, we use regression analysis to clarify the basic patterns laid out above. This helps sort out background changes in employment from responses to the earnings test. We exploit variation in earnings test parameters experienced by cohorts at different ages and in different years. This approach identifies the presence of dynamic effects resulting from changes in earnings test parameters by comparing estimated effects on labor supply of only current earnings test parameters, compared with past and anticipated future parameters. However, we cannot discern the full extent of these effects, given inherent limitations of our reduced-form approach that are discussed below.

To undertake this analysis, we compute means by age and year of the variables we analyzed above - employment, full-time employment, and earnings at different parts of the earnings distribution - and regress the cell means on earnings test parameters. The parameters include not just dummies for the earnings test being in place, as in much of the recent research, but also the value of the earnings test threshold. This offers a way to incorporate much additional variation from the 1996 and 2000 rule changes. While Gruber and Orszag (2003) also

\footnotetext{
${ }^{20}$ As a deflator, we use Social Security earnings growth, as reflected in the normal annual increases in the earnings test threshold.

${ }^{21}$ Manchester and Song report annual earnings at the 60,70 , and $80^{\text {th }}$ percentiles in 1999 for white males aged 6569 of $\$ 14,961, \$ 21,901$, and $\$ 34,874$. In our data, the amounts are $\$ 18,000$, $\$ 26,374$, and $\$ 45,000$.
} 
included the current values of both variables (the earnings threshold and earnings test dummy), we extend the analysis by adding values that are anticipated in the future and that were experienced in the past. Lastly, we include a full set of age and year dummies to difference out fixed age and time patterns in labor supply.

In total, we will use four variables that reflect current and future earnings test thresholds at the current age and at age 62 (or age 65 in another set of estimates), with four parallel variables for earnings test dummies. The first set of variables are the current earnings threshold and the current earnings test dummy. The second are the values of the threshold and earnings test dummy that are anticipated from the current age until 69. As we explained in reference to Table 2, we assume that people anticipate normal increases in the threshold associated with wage inflation, but not law changes. We depart from Table 2 by setting the value of the earnings threshold at zero when there is no earnings test; we chose a high value (of \$50,000) for exposition purposes when we used Table 2 to describe the identifying variation, but in the regressions we use the earnings test dummies to control for these instances. Lastly, we include a third and fourth set of variables that are analogous to the current and anticipated values just described, except they are the values experienced by the cohort at age 62 .

A few limitations of this reduced-form approach need to be recognized. We hypothesize that the estimated coefficients are negative for the earnings test dummy and positive for the earnings test threshold. Yet, if the latter is too positive relative to the former, then eliminating the earnings test (which sets the threshold as well as the dummy to zero) would reduce labor supply. This condition is met in some of our results, though not all, while a structural model would impose it naturally. Moreover, this reduced-form approach cannot capture all of the dynamic effects that might arise. In our formulation, we will miss some responses that generate persistence at ages other than 62 and 65. This limitation arises because we cannot control for changes in four values - the annual and anticipated thresholds and earnings test dummies - at every single past age. Capturing these effects would require a structural model that incorporates both expectations and dynamic constraints of the type that we have been highlighting. Thus, our analysis identifies the presence of dynamic effects at some ages, rather than their full consequences.

In order to define our sample for the regression analysis, we use ages 62 to 74 so as to focus on ages affected by past and present earnings test rules. Our time period covers the years 
1992 to 2003-2005 (depending on the data set and variable) so as to include a few years before the 1996 and after the 2000 changes. We also limit the sample by beginning with the 1925 birth cohort, which turned 65 in 1990, since earlier cohorts experienced a higher benefit reduction rate when they turned 65 before 1990, and that might have altered their labor supply after age 65.

\section{Regression results.}

By way of comparison, we first report results in Table 4 that include only the current value of the earnings test threshold and earnings test dummy, along with a full set of age and year effects. A higher value of the current threshold raises labor supply in Table 4, as measured by employment, full-time employment, and earnings, and removing the earnings test raises labor supply as well.

Importantly, the results differ somewhat depending on the measure of labor supply. The estimated effects of earnings test parameters are generally significant except when using measures of current labor supply from the CPS. These measures report whether someone had a job or worked full-time last week, while the other measures report whether someone worked at all or usually worked full-time or what they earned over a full year. Since the earnings test depends on labor supply and earnings for the year, the variables based on last week's status measure annual labor supply with more error, which may explain the weaker results.

The full set of results for the age-62 and age-65 perspectives are reported in Tables 5 and 6, respectively. Now, current values of earnings test parameters are less important when we include measures of future and past parameters. The current values remain significant in a few instances, and more often in the age-65 analysis, while the variables reflecting future and past values are significant in some of the other specifications. Joint F-tests give only occasional evidence of multicollinearity, but in any case we will consider the joint effect of all the coefficients in simulations that we undertake shortly. ${ }^{22}$

The upper and middle panels of Table 5 show results for employment and full-time employment, and the lower panel shows results for earnings on different parts of the earnings distribution. In the upper panel, we find significant effects of values anticipated at age 62 on employment, as measured by having a job last week. A higher present value of the earnings threshold anticipated at age 62 significantly raises employment at all ages, and a greater number

${ }^{22}$ When we test the joint significance of the earnings test parameters, there are a few specifications for which the pvalue on the F-statistic for all the parameters taken together is lower than the p-values on the current values tested separately from the past and anticipated future values. 
of years in which the earnings test is expected to apply, as anticipated at age 62, significantly reduces employment. A $10 \%$ increase in the present value of the future threshold values results in almost a half-percentage-point increase in employment at the current age. The 1996 legislation raised the log of the present value of future threshold amounts by 0.40 , when comparing the cohort reaching age 62 in 1995 versus 1996. This implies a $0.40 * 0.0445=1.8$ percentage point increase in employment for the latter cohort, which is a sizeable share of the 5-6 point gain for workers in their 60s throughout the period we examine.

Next, it should be noted that the results are sensitive to the definition of work status, as we also found for the preliminary results in Table 4. When the dependent variable is defined as working at all during the year rather than having a job last week, the estimated effects of earnings test parameters that were anticipated at age 62 remain similar in magnitude but are no longer statistically significant. The current value of the earnings test threshold is now larger and significant, with a $10 \%$ increase implying an 0.19 percentage point increase in employment (and recall that the 1996 legislation raised the threshold by close to 10\% per year through 1999). When, instead, employment is defined based on having any annual earnings in the HRS, several of the coefficients are substantially larger; the estimated effects of the earnings threshold and earnings test dummy values that were anticipated at age 62 are more than twice as large.

A last point with regards to the employment results arises from an interesting contrast with the graphs presented earlier. In Figure 3, we demonstrated the importance of controlling for last year's labor supply when evaluating the effect of current earnings test parameters. In Table 5, controlling for earnings test parameters that were anticipated well in the past helps deal with these concerns. Earnings test parameters anticipated at age 62 have sizeable effects on overall employment but not on current employment conditional on working last year. On the other hand, earnings test parameters that are currently anticipated until age 69 have bigger, though still insignificant, effects on the latter than on the former.

When we turn our focus to full-time employment in the middle panel of Table 5 , the results are generally similar, which is unsurprising because liberalizing the earnings test should encourage more full-time work at the expense of either part-time work or employment. The values of earnings test parameters that were anticipated at age 62 have significant effects on working full-time last week, and they are very similar in magnitude to the first set of results we discussed for having a job last week. The current earnings test dummy now has a sizeable 
negative and close to significant effect. We find greater effects for working full-time last year than for working at all last year, with statistically significant effects for the current value of the threshold, almost significant effects for the current earnings test dummy, and statistically significant effects for both values as anticipated at age 62 .

In the lower panel of Table 5, we analyze changes in earnings by looking at behavior on different parts of the earnings distribution and/or budget constraint. Manchester and Song found two interrelated effects. They showed that earnings in the $20^{\text {th }}-40^{\text {th }}$ percentiles declined somewhat for ages 65-69 after 2000, and earnings in the $60^{\text {th }}-80^{\text {th }}$ percentiles increased a great deal, showing that people responded by shifting their earnings up. However, it is less straightforward to undertake this analysis by doing a cross-age comparison, since the conditional earnings distribution differs greatly with age. We find several significant effects, but they are somewhat difficult to interpret, so we will discuss their implications in a simulation exercise momentarily.

Lastly, we also employed a simpler test by measuring the percentage of the full sample workers and non-workers - who had earnings above the earnings test threshold that applies at ages 62-64. This is a relatively low amount that rose by the rate of wage inflation throughout the period but was not affected by legislation, and it may capture persistent labor supply responses that begin at ages 62-64. We find that several of the parameters have significant effects on the likelihood of earning more than the age 62-64 threshold. Higher values of the current and anticipated thresholds, along with the thresholds anticipated at age 62, raises this likelihood, while the earnings test being in place or anticipated at age 62 to be in place for longer reduces it.

In Table 6, we define the retrospective earnings test parameters from an age-65 rather than an age-62 perspective, and we limit the sample to ages 65-74. We find fewer significant effects, possibly because we have lost information (since age-65 surprises for a cohort are shorter-lived than age-62 surprises) that helps to distinguish earnings test responses from underlying labor supply changes. Of interest, though, are significant effects that correspond to the patterns in Figures 2-B and 2-C. For example, the current earnings test threshold and current earnings test dummy significantly raise the proportion of the sample returning to work, which is driven by the immediate response in 2000 at ages 65-69 that we saw in Figure 2-C.

Understanding the overall effect of a change in earnings test rules, which alter actual and anticipated values over a period of time, is now more complicated. We use our estimates to 
simulate the elimination of the earnings test in 2000. To do so, we determine how current and anticipated values of the threshold and earnings test dummy were affected, and then how those shifts got transmitted to labor supply via the estimated coefficients that we have discussed. Since the estimates for current measures of labor supply were often less robust, we focus on full-year measures. Recall, also, that the specifications are restrictive in allowing the earnings test to generate persistence by altering labor supply only at age 62 and not at other past ages.

When we predict the effect of eliminating the earnings test in 2000 on working at all during the year as reported in the CPS, we find increases at ages 66-68 of about a half percentage point and an increase at age 65 of 1.3 percentage points. The predicted effects on the same variable from the HRS are substantially greater. Employment in 2000 is predicted to rise by around two percentage points at ages $66-69$ and by 3.5 points at age 65. As cohorts then age, employment remains about a percentage point (1.5) higher in 2001 and about a half a percentage point (0.9) higher in 2002 for ages 66-69 (age 65). Moreover, employment rates at younger ages increase by about one percentage point due to the shock to anticipated values.

We also found notable effects of the 2000 change on earnings at different parts of the distribution. We find declines of a few hundred dollars in average earnings in 2000 between the $20^{\text {th }}$ and $40^{\text {th }}$ percentiles of the earnings distribution, and gains of up to a few thousand dollars in the the $60^{\text {th }}-80^{\text {th }}$ percentiles. Consistent with this, we also find increases in the percentage earnings above the earnings threshold of a half to a whole percentage point for workers in their late 60s in 2000.

\section{CONCLUSIONS}

In this study, we consider several issues that have received little attention in studies of recent earnings test changes. First, while other studies have investigated the effects of the elimination of the earnings test in 2000 for ages 65-69, we also consider the increases in the earnings test threshold for the same age group that were instituted gradually beginning in 1996. The elimination in 2000 should be considered against a backdrop in which the earnings test threshold was already rising and was expected to reach considerable amounts in 2000-2002.

Second, we use data on labor force transitions to show that conditioning on last year's labor supply is important in identifying responses to earnings test changes in the current year. 
We find major differences in how workers and non-workers responded to the recent changes, and that flows into full-time versus part-time work were altered as well.

Third, we develop a regression framework to analyze how the persistence of labor supply choices influenced responses to earnings test changes. Our results reveal significant effects of past and anticipated future earnings test rules on current labor supply. These effects are masked when considering the impact of only current earnings test parameters. As a consequence, earnings test changes can affect labor supply of younger and older workers in addition to the directly affected group.

The research presented here can be extended with a careful investigation of sources of persistence in labor supply choices at older ages. Since the earnings test can interact with these features in important ways, the recent changes in earnings test rules that we have emphasized offer an opportunity to learn more about their importance. As we noted earlier, research in this vein has growing relevance as workers in their early 60s are delaying retirement at increasing rates in recent years. 


\section{REFERENCES}

Altonji, Joseph, and Christina Paxson. 1988. "Labor Supply Preferences, Hours Constraints, and Hours-Wage Trade-offs.” Journal of Labor Economics 6, 254-276.

Burtless, Gary, and Robert A. Moffitt. 1985. "The Joint Choice of Retirement Age and PostRetirement Hours of Work.” Journal of Labor Economics 3, 209-236.

Card, David. 1990. "Labor Supply with a Minimum Hours Threshold.” Carnegie-Rochester Conference Series on Public Policy 33, 137-168.

Cogan, John F. 1981. “Fixed Costs and Labor Supply.” Econometrica 49, 945-963.

Coile, Courtney, Peter Diamond, Jonathan Gruber, and Alain Jousten. 2002. “Delays in Claiming Social Security Benefits.” Journal of Public Economics 84 (3), 357-386.

Economic Report of the President. Washington: U.S. Government Printing Office, February 1999.

Friedberg, Leora. 1998. “The Social Security Earnings Test and Labor Supply of Older Men,” in James Poterba (ed.), Tax Policy and the Economy, Volume 12 (Cambridge, MA: MIT Press).

Friedberg, Leora. 2000. “The Labor Supply Effects of the Social Security Earnings Test.” The Review of Economics and Statistics 82 (1), 46-63.

Friedberg, Leora. 2002. “The Trend Towards Part-Time Work among Older Workers,” unpublished manuscript, University of Virginia.

Gruber, Jonathan, and Peter Orszag. 2003. "Does the Social Security Earnings Test Affect Labor Supply and Benefits Receipt?” National Tax Journal (December), 755-73.

Gustman, Alan, and Thomas Steinmeier. 1986. “A Structural Retirement Model.” Econometrica 54, 555-584.

Gustman, Alan, and Thomas Steinmeier. 1999. "What People Don’t Know About Their Pensions and Social Security: An Analysis Using Linked Data From the Health and Retirement Study.” National Bureau of Economic Research Working Paper No. 7368.

Haider, Steven, and David Loughran. 2006. "Do Elderly Men Respond to Taxes on Earnings? Evidence from the Social Security Retirement Earnings Test.” Draft, Michigan State University.

Hurd, Michael. 1996. “The Effect of Labor Market Rigidities on the Labor Force Behavior of Older Workers,” in Wise, David (ed.), Advances in the Economics of Aging. Chicago: University of Chicago Press, 11-58. 
Kristof, Kathy, "Personal Finance," Los Angeles Times (September 5, 1997), D5.

Polivka, Anne, and Steven Miller. 1998. "The CPS After the Redesign: Refocusing the Economic Lens," in Labor Statistics Measurement Issues, J.Haltiwanger, M.Manser, and R.Topel, eds., Chicago: University of Chicago Press, 249-286.

Reimers, Cordelia, and Marjorie Honig, "The Perceived Budget Constraint under Social Security: Evidence from Reentry Behavior," Journal of Labor Economics 11(1993), 184-204.

Reimers, Cordelia, and Marjorie Honig, "Responses to Social Security by Men and Women: Myopic and Far-Sighted Behavior," Journal of Human Resources 31 (1996), 359-382.

Rust, John, and Christopher Phelan. 1997. "How Social Security and Medicare Affect Retirement Behavior In a World of Incomplete Markets.” Econometrica 65 (4), 781-831.

Ruhm, Christopher. 1990. "Bridge Jobs and Partial Retirement.” Journal of Labor Economics 8, 482-501.

Saez, Emmanuel. 2002. "Do Taxpayers Bunch at Kinkpoints.” Manuscript, University of California, Berkeley.

Simon, Ruth, "How To Be Sure You Never Go Broke," Money 25 (October 1996), 100-114.

Song, Jae, and Joyce Manchester. 2006. "New Evidence on Earnings and Benefit Claims Following Changes in the Retirement Earnings Test in 2000.” U.S. Social Security Administration, Office of Research, Evaluation, and Statistics Working Paper No. 107.

Stewart, Jay. 2002. "Recent Trends in Job Stability and Job Security: Evidence from the March CPS.” U.S. Bureau of Labor Statistics, BLS Working Paper 356, March.

Stewart, Jay. 2005. "Using March CPS Data to Analyze Labor Market Transitions." Manuscript, U.S. Bureau of Labor Statistics, July.

Tran, Bac. 2004. "The Effect of the Repeal of the Retirement Earnings Test on the Labor Supply of Older Workers.” Unpublished manuscript, University of Maryland.

United States Social Security Administration. 2005. Annual Statistical Supplement to the Social Security Bulletin, 2005 (Washington, DC).

Vroman, Wayne. 1985. "Some Economic Effects of the Retirement Test," in Ronald Ehrenberg (ed.), Research in Labor Economics, Volume 7 (Greenwich, CT: JAI Press Inc.). 
TABLE 1

Earnings test rules

\begin{tabular}{|c|c|c|c|c|c|c|c|}
\hline \multirow[b]{2}{*}{ Year } & \multicolumn{3}{|c|}{ Younger age group } & \multicolumn{3}{|c|}{ Older age group } & \multirow{2}{*}{$\begin{array}{c}\text { Full } \\
\text { Retirement } \\
\text { Age (FRA) } \\
\end{array}$} \\
\hline & ages & $\begin{array}{l}\text { earnings } \\
\text { threshold }\end{array}$ & $\begin{array}{l}\text { tax } \\
\text { rate }\end{array}$ & ages & $\begin{array}{l}\text { earnings } \\
\text { threshold }\end{array}$ & $\begin{array}{c}\text { tax } \\
\text { rate }\end{array}$ & \\
\hline 1989 & 62 to 64 & $\$ 6480$ & $50 \%$ & 65 to 69 & $\$ 8880$ & $50 \%$ & 65 \\
\hline 1990 & " & 6840 & $"$ & " & 9360 & $33^{1 / 3}$ & $"$ \\
\hline 1991 & $"$ & 7080 & $"$ & $"$ & 9720 & $"$ & $"$ \\
\hline 1992 & $"$ & 7440 & $"$ & $"$ & 10200 & $"$ & $"$ \\
\hline 1993 & $"$ & 7680 & $"$ & $"$ & 10560 & $"$ & $"$ \\
\hline 1994 & $"$ & 8040 & $"$ & $"$ & 11160 & $"$ & $"$ \\
\hline 1995 & $"$ & 8160 & $"$ & $"$ & 11280 & $"$ & $"$ \\
\hline 1996 & $"$ & 8280 & $"$ & $"$ & 12500 & $"$ & $"$ \\
\hline 1997 & $"$ & 8640 & $"$ & $"$ & 13500 & $"$ & $"$ \\
\hline 1998 & $"$ & 9120 & $"$ & $"$ & 14500 & $"$ & $"$ \\
\hline 1999 & $"$ & 9600 & " & " & 15500 & $"$ & " \\
\hline 2000 & $\begin{array}{l}62 \text { until Dec } \\
\text { before } \\
\text { reaches FRA }\end{array}$ & 10080 & $"$ & $\begin{array}{l}\text { Jan until month } \\
\text { reaches FRA }\end{array}$ & 17000 & $"$ & $\begin{array}{c}65+2 \\
\text { months }\end{array}$ \\
\hline 2001 & $"$ & 10680 & $"$ & $"$ & 25000 & $"$ & $65+4$ \\
\hline 2002 & $"$ & 11280 & $"$ & $"$ & 30000 & $"$ & $65+6$ \\
\hline 2003 & $"$ & 11520 & $"$ & $"$ & 30720 & $"$ & $65+8$ \\
\hline 2004 & $"$ & 11640 & $"$ & $"$ & 31080 & $"$ & $65+10$ \\
\hline 2005 & $"$ & 12000 & $"$ & $"$ & 31800 & $"$ & 66 \\
\hline 2006 & $"$ & 12480 & $"$ & $"$ & 33240 & $"$ & 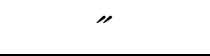 \\
\hline
\end{tabular}

Source: United States Social Security Administration (2005).

Notes: The Full Retirement Age is that of insured workers turning 62 in the year in question.

" indicates that the same value applies from the cell above. 
TABLE 2: The earnings test threshold and the employment rate, by cohort and year

\begin{tabular}{|c|c|c|c|c|c|c|c|c|c|c|c|c|c|}
\hline Birth cohort & 1928 & 1929 & 1930 & 1931 & 1932 & 1933 & 1934 & 1935 & 1936 & 1937 & 1938 & 1939 & 1940 \\
\hline Year & \multicolumn{13}{|c|}{ Panel A: Actual value of the earnings test threshold (\$) } \\
\hline 1992 & 7440 & 7440 & 7440 & - & - & - & - & - & - & - & - & - & - \\
\hline 1993 & 10560 & 7680 & 7680 & 7680 & - & - & - & - & - & - & - & - & - \\
\hline 1994 & 11160 & 11160 & 8040 & 8040 & 8040 & - & - & - & - & - & - & - & - \\
\hline 1995 & 11280 & 11280 & 11280 & 8160 & 8160 & 8160 & - & - & - & - & - & - & - \\
\hline 1996 & 12500 & 12500 & 12500 & 12500 & 8280 & 8280 & 8280 & - & - & - & - & - & - \\
\hline 1997 & 13500 & 13500 & 13500 & 13500 & 13500 & 8640 & 8640 & 8640 & - & - & - & - & - \\
\hline 1998 & - & 14500 & 14500 & 14500 & 14500 & 14500 & 9120 & 9120 & 9120 & - & - & - & - \\
\hline 1999 & - & - & 15500 & 15500 & 15500 & 15500 & 15500 & 9600 & 9600 & 9600 & - & - & - \\
\hline 2000 & - & - & - & - & - & - & - & $17000^{*}$ & 10080 & 10080 & 10080 & - & - \\
\hline 2001 & - & - & - & - & - & - & - & - & $25000^{*}$ & 10680 & 10680 & 10680 & - \\
\hline 2002 & - & - & - & - & - & - & - & - & - & $30000^{*}$ & 11280 & 11280 & 11280 \\
\hline 2003 & - & - & - & - & - & - & - & - & - & - & $30720^{*}$ & 11520 & 11520 \\
\hline 2004 & - & - & - & - & - & - & - & - & - & - & - & $31080^{*}$ & 11640 \\
\hline Year & \multicolumn{13}{|c|}{ Panel B: Anticipated value of the earnings test threshold at age 62 (\$) } \\
\hline 1992 & 7440 & 7440 & 7440 & - & - & - & - & - & - & - & - & - & - \\
\hline 1993 & 10560 & 7680 & 7680 & 7680 & - & - & - & - & - & - & - & - & - \\
\hline 1994 & 11160 & 11160 & 8040 & 8040 & 8040 & - & - & - & - & - & - & - & - \\
\hline 1995 & 11280 & 11280 & 11280 & 8160 & 8160 & 8160 & - & - & - & - & - & - & - \\
\hline 1996 & 11446 & 11446 & 11446 & 11446 & 8280 & 8280 & 8280 & - & - & - & - & - & - \\
\hline 1997 & 11944 & 11944 & 11944 & 11944 & 11944 & 8640 & 8640 & 8640 & - & - & - & - & - \\
\hline 1998 & - & 12607 & 12607 & 12607 & 12607 & 12607 & 9120 & 9120 & 9120 & - & - & - & - \\
\hline 1999 & - & - & 13271 & 13271 & 13271 & 13271 & 15500 & 9600 & 9600 & 9600 & - & - & - \\
\hline 2000 & - & - & - & 13934 & 13934 & 13934 & 17000 & $17000^{*}$ & 10080 & 10080 & 10080 & - & - \\
\hline 2001 & - & - & - & - & 14764 & 14764 & 25000 & 25000 & $25000^{*}$ & 10680 & 10680 & 10680 & - \\
\hline 2002 & - & - & - & - & - & 15593 & 30000 & 30000 & 30000 & $30000^{*}$ & 11280 & 11280 & 11280 \\
\hline 2003 & - & - & - & - & - & - & 30720 & 30720 & 30720 & 30720 & $30720^{*}$ & 11520 & 11520 \\
\hline \multirow[t]{2}{*}{2004} & - & - & - & - & - & - & - & 31080 & 31080 & 31080 & - & $31080^{*}$ & 11640 \\
\hline & \multicolumn{13}{|c|}{ Panel C: Discounted present value, summed up over ages 62-69, by birth cohort } \\
\hline actual & 69400 & 73452 & 77957 & 109471 & 140683 & 171887 & 203430 & 230438 & 229278 & 229265 & 228310 & 227089 & 225846 \\
\hline anticipated & 67314 & 69810 & 72445 & 75323 & 78659 & 82265 & 122545 & 136052 & 147079 & 151558 & 228310 & 227089 & 225846 \\
\hline
\end{tabular}

See notes on next page. 
Panels A and B: * indicates those years, beginning in 2000, in which the Full Retirement Age was rising above the age of 65. Before the 2000 legislation, people who turned 65 would have faced the earnings test rules that applied for younger workers until they reached the FRA, and then the earnings test rules that applied for older workers. The 2000 legislation stipulated that, after reaching the FRA, no earnings test would apply, and in the calendar year in which someone will reach the FRA but before they do, the rules that were set in 1996 for older workers apply.

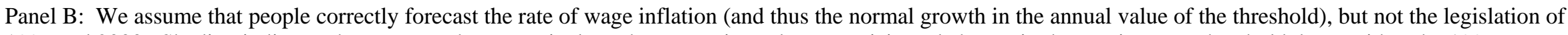
1996 and 2000. Shading indicates those years when a particular cohort experienced an unanticipated change in the earnings test threshold due to either the 1996 legislation (shaded lightly), the 2000 legislation (shaded medium), or both (shaded darkly). For anticipated values of the earnings test threshold that were never realized, we applied the rate of increase in the age 62-64 threshold in the same year.

Panel C: To compute the expected present values of the earnings test thresholds summed over ages $62-69$, we use a $3 \%$ discount rate, and we treat the absence of the earnings test as equivalent to setting the threshold at \$50,000 (so as not to confuse it with the presence of an earnings test with a threshold value of \$0). Also, in computing the present value, we account for the increase in the Full Retirement Age by two months per year beginning in 2000, noted in the table with *; we use as an approximation the weighted average of the value of the threshold at younger ages and the value that applies in the calendar year in which one reaches the FRA; the weight on the latter is the number of months divided by twelve by which the FRA exceeded the age of 65 that year. 
TABLE 3

Means (standard errors) of key variables

\begin{tabular}{l|cccc|}
\hline \multirow{2}{*}{} & \multicolumn{4}{|c|}{ March Current Population Survey, 1992-2005 } \\
\cline { 2 - 5 } & age: 55-61 & age: 62-64 & age: 65-69 & age: $70-74$ \\
\hline age & $57.8(2.0)$ & $63.0(0.8)$ & $66.9(1.4)$ & $71.9(1.4)$ \\
worked last year & 0.705 & 0.491 & 0.296 & 0.169 \\
$\quad$ real earnings last year & $46,749(53,686)$ & $39,568(52,337)$ & $30,582(48,022)$ & $25,705(46,689)$ \\
working now & 0.900 & 0.798 & 0.760 & 0.744 \\
full-time last week & 0.791 & 0.662 & 0.501 & 0.398 \\
working last week & 0.642 & 0.399 & 0.232 & 0.131 \\
$\quad$ full-time last week & 0.787 & 0.656 & 0.494 & 0.392 \\
working last week: & & & & \\
1992-95 & 0.616 & 0.364 & 0.209 & 0.116 \\
1996-99 & 0.641 & 0.393 & 0.219 & 0.126 \\
2000-05 & 0.654 & 0.422 & 0.256 & 0.144 \\
$\mathrm{~N}$ & 126,352 & 45,817 & 71,023 & 62,770 \\
\hline
\end{tabular}

The CPS samples are weighted using March supplement weights to make the statistics nationally representative. 
TABLE 4: Regression results, current earnings test parameters only

\begin{tabular}{|c|c|c|c|c|}
\hline \multirow[b]{2}{*}{$\begin{array}{l}\text { Selected independent } \\
\text { variables }\end{array}$} & \multicolumn{4}{|c|}{ Dependent variable, means computed by birth cohort and year } \\
\hline & \multicolumn{2}{|c|}{$\begin{array}{cc}\begin{array}{c}\text { had a job last } \\
\text { week }\end{array} & \begin{array}{c}\text { worked last } \\
\text { year }\end{array} \\
\end{array}$} & $\begin{array}{c}\text { earned }>0 \text { this } \\
\text { year, HRS }\end{array}$ & $\begin{array}{c}\text { had job last wk if } \\
\text { worked last yr }\end{array}$ \\
\hline \multirow{2}{*}{$\begin{array}{l}\text { Log of earnings test } \\
\text { threshold/1000 } \\
\text { Earnings test in place? }\end{array}$} & $0.0041(0.0082)$ & $0.0120(0.0088)$ & 0.0535 (0.0238) & $0.0100(0.0162)$ \\
\hline & $-0.0164(0.0229)$ & $-0.0435(0.0244)$ & $-0.1504(0.0655)$ & $-0.0219(0.0454)$ \\
\hline \multirow{5}{*}{$\begin{array}{l}\text { Sample size } \\
\text { years included } \\
\text { cohorts included } \\
\text { ages included }\end{array}$} & 154 & \multirow{2}{*}{$\begin{array}{c}135 \\
1992-2004\end{array}$} & \multirow{2}{*}{$\begin{array}{c}128 \\
1992-2003\end{array}$} & 154 \\
\hline & $1992-2005$ & & & $1992-2005$ \\
\hline & $1925-1943$ & 1925-1942 & $1925-1941$ & $1925-1943$ \\
\hline & $62-74$ & $62-73$ & $62-74$ & $62-74$ \\
\hline & $\begin{array}{c}\text { had job last wk if } \\
\text { no work last yr }\end{array}$ & $\begin{array}{l}\text { worked full- } \\
\text { time last week }\end{array}$ & $\begin{array}{l}\text { usually full- } \\
\text { time last year }\end{array}$ & $\begin{array}{l}\text { FT last week if } \\
\text { worked last yr }\end{array}$ \\
\hline \multirow{2}{*}{$\begin{array}{l}\text { Log of threshold } / 1000 \\
\text { Earnings test in place? }\end{array}$} & $0.0012(0.0022)$ & $0.0171(0.0061)$ & $0.0139(0.0062)$ & $0.0294(0.0226)$ \\
\hline & $-0.0048(0.0062)$ & $-0.0480(0.0172)$ & $-0.0451(0.0173)$ & $-0.0918(0.0634)$ \\
\hline \multirow{5}{*}{$\begin{array}{l}\text { Sample size } \\
\text { cohorts included } \\
\text { years included } \\
\text { ages included }\end{array}$} & 154 & \multirow{2}{*}{$\begin{array}{c}154 \\
1925-1943\end{array}$} & \multirow{2}{*}{$\begin{array}{c}135 \\
1925-1942\end{array}$} & 154 \\
\hline & $1925-1943$ & & & $1925-1943$ \\
\hline & $1992-2005$ & $1992-2005$ & 1992-2004 & 1992-2005 \\
\hline & $62-74$ & $62-74$ & $62-73$ & \multirow{2}{*}{ 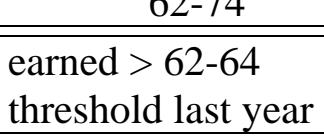 } \\
\hline & \multicolumn{2}{|c|}{$\begin{array}{l}\text { real earnings last year } \\
\text { in } 20^{\text {th }}-40^{\text {th }} \text { percentiles }\end{array}$} & $\begin{array}{ll}\text { Ings last year } & \mathrm{e} \\
\text { th } & \\
\text { percentiles } & \mathrm{t} \\
\end{array}$ & \\
\hline \multirow{2}{*}{$\begin{array}{l}\text { Log of threshold/1000 } \\
\text { Earnings test in place? }\end{array}$} & \multirow{2}{*}{$\begin{array}{l}190.7(423.5) \\
309.2(1214.6)\end{array}$} & \multicolumn{2}{|c|}{$1915.9(1446.9)$} & $0.0145(0.0066)$ \\
\hline & & -8794 & $3(4149.5)$ & $0.0448(0.0185)$ \\
\hline $\begin{array}{l}\text { Sample size } \\
\text { cohorts included } \\
\text { years included } \\
\text { ages included }\end{array}$ & $\begin{array}{c}114 \\
1925-1942 \\
1992-2004 \\
62-69,70+71,72\end{array}$ & $62-6$ & $\begin{array}{c}114 \\
925-1942 \\
992-2004 \\
70+71,72+73\end{array}$ & $\begin{array}{c}135 \\
1925-1942 \\
1992-2004 \\
62-73 \\
\end{array}$ \\
\hline
\end{tabular}

Notes: Data from March Current Population Surveys of 1992-2005. All regressions include year and age effects as well. Additional details are provided in the text. 
TABLE 5: Regression results (age-62 perspective)

\begin{tabular}{|c|c|c|c|c|}
\hline \multirow[b]{2}{*}{$\begin{array}{l}\text { Selected independent } \\
\text { variables }\end{array}$} & \multicolumn{4}{|c|}{ Dependent variable, means computed by birth cohort and year } \\
\hline & $\begin{array}{c}\text { had a job last } \\
\text { week }\end{array}$ & $\begin{array}{c}\text { worked last } \\
\text { year }\end{array}$ & $\begin{array}{c}\text { earned }>0 \text { this } \\
\text { year, HRS }\end{array}$ & $\begin{array}{c}\text { had job last wk if } \\
\text { worked last yr }\end{array}$ \\
\hline \multicolumn{5}{|l|}{$\begin{array}{l}\text { Log of earnings test } \\
\text { threshold } 1000\end{array}$} \\
\hline current value & $0.0029(0.0109)$ & $0.0196(0.0120)$ & $0.0166(0.0320)$ & $-0.0006(0.0220)$ \\
\hline PV, anticipated to 69 & $-0.0015(0.0071)$ & $-0.0097(0.0079)$ & $0.0045(0.0204)$ & $0.0150(0.0143)$ \\
\hline value at age 62 & $0.1006(0.1125)$ & $0.0283(0.1342)$ & $0.1215(0.3602)$ & $0.2773(0.2262)$ \\
\hline PV, anticipated 62-69 & $0.0445(0.0166)$ & $0.0306(0.0197)$ & $0.1295(0.0536)$ & $0.0125(0.0333)$ \\
\hline \multirow{5}{*}{$\begin{array}{l}\text { Earnings test in place? } \\
\text { current dummy } \\
\text { PV, anticipated to } 69 \\
\text { PV, anticipated } 62-69\end{array}$} & & \multirow[b]{2}{*}{$-0.0328(0.0275)$} & \multirow[b]{2}{*}{$-0.0725(0.0700)$} & \\
\hline & $-0.0058(0.0263)$ & & & $-0.0340(0.0530)$ \\
\hline & $0.0014(0.0029)$ & $0.0039(0.0033)$ & $-0.0046(0.0086)$ & $-0.0054(0.0058)$ \\
\hline & $-0.0136(0.0056)$ & $-0.0095(0.0066)$ & $-0.0524(0.0179)$ & $0.0033(0.0112)$ \\
\hline & $\begin{array}{c}\text { had job last wk if } \\
\text { no work last yr }\end{array}$ & $\begin{array}{l}\text { worked full- } \\
\text { time last week }\end{array}$ & $\begin{array}{l}\text { usually full- } \\
\text { time last year }\end{array}$ & $\begin{array}{l}\text { FT last week if } \\
\text { worked last yr }\end{array}$ \\
\hline \multirow{4}{*}{$\begin{array}{l}\text { Log of threshold/1000 } \\
\text { current value } \\
\text { PV, anticipated to } 69 \\
\text { value at age } 62 \\
\text { PV, anticipated } 62-69\end{array}$} & $0.0001(0.0030)$ & $0.0123(0.0079)$ & 0.0160 (0.0084) & $0.0472(0.0305)$ \\
\hline & $0.0009(0.0020)$ & $-0.0011(0.0052)$ & $-0.0064(0.0055)$ & $-0.0018(0.0198)$ \\
\hline & $0.0296(0.0313)$ & $0.0099(0.0817)$ & 0.1335 (0.0939) & $0.2183(0.3137)$ \\
\hline & $0.0027(0.0046)$ & $0.0350(0.0120)$ & $0.0395(0.0137)$ & $0.0896(0.0462)$ \\
\hline \multirow{4}{*}{$\begin{array}{l}\text { Earnings test in place? } \\
\text { current dummy } \\
\text { PV, anticipated to } 69 \\
\text { PV, anticipated 62-69 }\end{array}$} & & & & \\
\hline & $-0.0043(0.0073)$ & $-0.0297(0.0191)$ & $-0.0287(0.0194$ & $-0.1252(0.0734)$ \\
\hline & $-0.0004(0.0008)$ & $0.0001(0.0021)$ & 0.001 & $0.0097(0.0081)$ \\
\hline & $-0.0004(0.0016)$ & $-0.0125(0.0041)$ & $-0.0102(0.0046$ & $-0.0237(0.0156)$ \\
\hline Log of threshold/1000 & $\begin{array}{l}\text { real earnings las } \\
\text { in } 20^{\text {th }}-40^{\text {th }} \text { perc }\end{array}$ & $\begin{array}{l}\text { real ea } \\
\text { in } 60^{\text {th }}\end{array}$ & $\begin{array}{l}\text { ngs last year } \\
\text { h percentiles }\end{array}$ & $\begin{array}{l}\text { rned > 62-64 } \\
\text { reshold last year }\end{array}$ \\
\hline current value & 555.5 (550.1) & & $0.9(1807.1)$ & $0.0180(0.0088)$ \\
\hline PV, anticipated to 69 & $-4.7(361.5)$ & -13 & 3.0 (1187.4) & $-0.0077(0.0058)$ \\
\hline value at age 62 & 14361 (6824.6) & & 46 (22417) & $0.0494(0.0090)$ \\
\hline PV, anticipated 62-69 & $2222.2 \quad$ (991.9) & & $09.4(3258.1)$ & $0.0335(0.0145)$ \\
\hline Earnings test in place? & & & & \\
\hline current dummy & $-1186.5(1303.5)$ & -989 & $4.2(4281.9)$ & $-0.0325(0.0203)$ \\
\hline PV, anticipated to 69 & 282.4 (155.8) & & 0.1 (511.7) & $0.0032(0.0024)$ \\
\hline PV, anticipated 62-69 & $-558.9(341.4)$ & & $0.3(1121.5)$ & $-0.0124(0.0089)$ \\
\hline
\end{tabular}

Notes: Data from March Current Population Surveys of 1992-2005. All regressions include year and age effects as well. Additional details are provided in the text. 
TABLE 6: Regression results (age-65 perspective)

\begin{tabular}{|c|c|c|c|c|}
\hline \multirow[b]{2}{*}{$\begin{array}{l}\text { Selected independent } \\
\text { variables }\end{array}$} & \multicolumn{4}{|c|}{ Dependent variable, means computed by birth cohort and year } \\
\hline & $\begin{array}{c}\text { had a job last } \\
\text { week }\end{array}$ & $\begin{array}{c}\text { worked last } \\
\text { year }\end{array}$ & $\begin{array}{c}\text { earned }>0 \text { this } \\
\text { year, HRS }\end{array}$ & $\begin{array}{c}\text { had job last wk if } \\
\text { worked last yr }\end{array}$ \\
\hline \multicolumn{5}{|l|}{$\begin{array}{l}\text { Log of earnings test } \\
\text { threshold } 1000\end{array}$} \\
\hline current value & $0.0132(0.0143)$ & $0.0193(0.0182)$ & $0.0073(0.0478)$ & $-0.0232(0.0333)$ \\
\hline PV, anticipated to 69 & $0.0033(0.0114)$ & $-0.0044(0.0145)$ & $-0.0073(0.0351)$ & $0.0396(0.0267)$ \\
\hline value at age 65 & $0.0246(0.0160)$ & $0.0093(0.0204)$ & $-0.0047(0.0496)$ & $0.0629(0.0374)$ \\
\hline PV, anticipated 65-69 & $-0.0359(0.0206)$ & $-0.0121(0.0267)$ & $0.0895(0.0671)$ & $-0.0858(0.0481)$ \\
\hline \multirow{5}{*}{$\begin{array}{l}\text { Earnings test in place? } \\
\text { current dummy } \\
\text { PV, anticipated to } 69 \\
\text { dummy at age } 65 \\
\text { PV, anticipated 65-69 }\end{array}$} & $-0.0553(0.0390)$ & $-0.0420(0.0491)$ & 0.0099 (0.1242) & $-0.0249(0.0911)$ \\
\hline & $-0.0003(0.0045)$ & $0.0003(0.0056)$ & $0.0042(0.0133)$ & $-0.0173(0.0104)$ \\
\hline & $-0.0554(0.0307)$ & \multirow{2}{*}{$\begin{array}{r}-0.0608(0.0512) \\
0.0138(0.0167)\end{array}$} & \multirow{2}{*}{$\begin{array}{r}0.1223(0.1755) \\
-0.0719(0.0499)\end{array}$} & $-0.1275(0.0717)$ \\
\hline & $0.0229(0.0117)$ & & & $0.0563(0.0274)$ \\
\hline & $\begin{array}{l}\text { had job last wk if } \\
\text { no work last yr }\end{array}$ & $\begin{array}{l}\text { worked full- } \\
\text { time last week }\end{array}$ & $\begin{array}{l}\text { usually full- } \\
\text { time last year }\end{array}$ & $\begin{array}{l}\text { FT last week if } \\
\text { worked last yr }\end{array}$ \\
\hline \multirow{4}{*}{$\begin{array}{l}\text { Log of threshold/1000 } \\
\text { current value } \\
\text { PV, anticipated to } 69 \\
\text { value at age } 65 \\
\text { PV, anticipated } 65-69\end{array}$} & 0.0064 & 0.0165 (0.0099) & $0.0197(0.0125)$ & 0.02 \\
\hline & $-0.0015(0.0030)$ & $-0.0042(0.0080)$ & $-0.0098(0.0100)$ & $-0.0082(0.0373)$ \\
\hline & $-0.0019(0.0042)$ & 0.0091 (0.0112) & $-0.0034(0.0140)$ & $(0.0522)$ \\
\hline & -0.0060 & $-0.0107(0.0144)$ & $-0.0021(0.0184)$ & $0.0672)$ \\
\hline Earnings test in place? & & & & \\
\hline current dummy & $-0.0213(0$ & $-0.0333(0.0272)$ & $-0.0295(0.0337)$ & $(0.1274)$ \\
\hline PV, anticipated to 69 & 0.0008 & $-0.0009(0.0031)$ & $0.0010(0.0038)$ & $(0.0146)$ \\
\hline dummy at age 65 & 0.0021( & $-0.0216(0.0214)$ & $-0.0155(0.0352)$ & $-0.0956(0.1002)$ \\
\hline PV, anticipated 65-69 & $0.0033(0.0031)$ & $0.0068(0.0082)$ & $0.0031(0.0115)$ & $0.0254(0.0383)$ \\
\hline Log of threshold/1000 & $\begin{array}{l}\text { real earnings las } \\
\text { in } 20^{\text {th }}-40^{\text {th }} \text { perc }\end{array}$ & $\begin{array}{l}\text { real } \\
\text { in } 60 \\
\end{array}$ & $\begin{array}{l}\text { gs last year } \\
\text { percentiles } \\
\end{array}$ & $\begin{array}{l}\text { earned }>62-64 \\
\text { threshold last year } \\
\end{array}$ \\
\hline & $-52.4(856.3)$ & & $.0(3156.7)$ & $0.0268(0.0128)$ \\
\hline PV, anticipated to 69 & $184.6(638.4)$ & & $.3(2353.5)$ & $-0.0126(0.0102)$ \\
\hline value a & $-878.8(885.8)$ & & $6(3265.4)$ & -0.000 \\
\hline PV, anticipated 65-69 & $-1025.6(1256.2)$ & & $.4(4664.2)$ & $0.0041(0.0188)$ \\
\hline Earnings test in place? & & & & \\
\hline current dummy & $679.4(2280.3)$ & & $.5(8406.4)$ & $-0.0394(0.0345)$ \\
\hline PV, anticipated to 69 & $523.2(242.5)$ & & $.2(893.9)$ & $0.0036(0.0039)$ \\
\hline dummy & $4273.5(2636.1)$ & & $6(9717.9)$ & $-0.0309(0.0360)$ \\
\hline PV, anticipated 65-69 & $-526.2(820.3)$ & & $0.1(3023.9)$ & 0.0017 (0.0117) \\
\hline
\end{tabular}

Notes: Data from March Current Population Surveys of 1992-2005. All regressions include year and age effects as well. Additional details are provided in the text. 


\section{FIGURE 1: The Earnings Test}

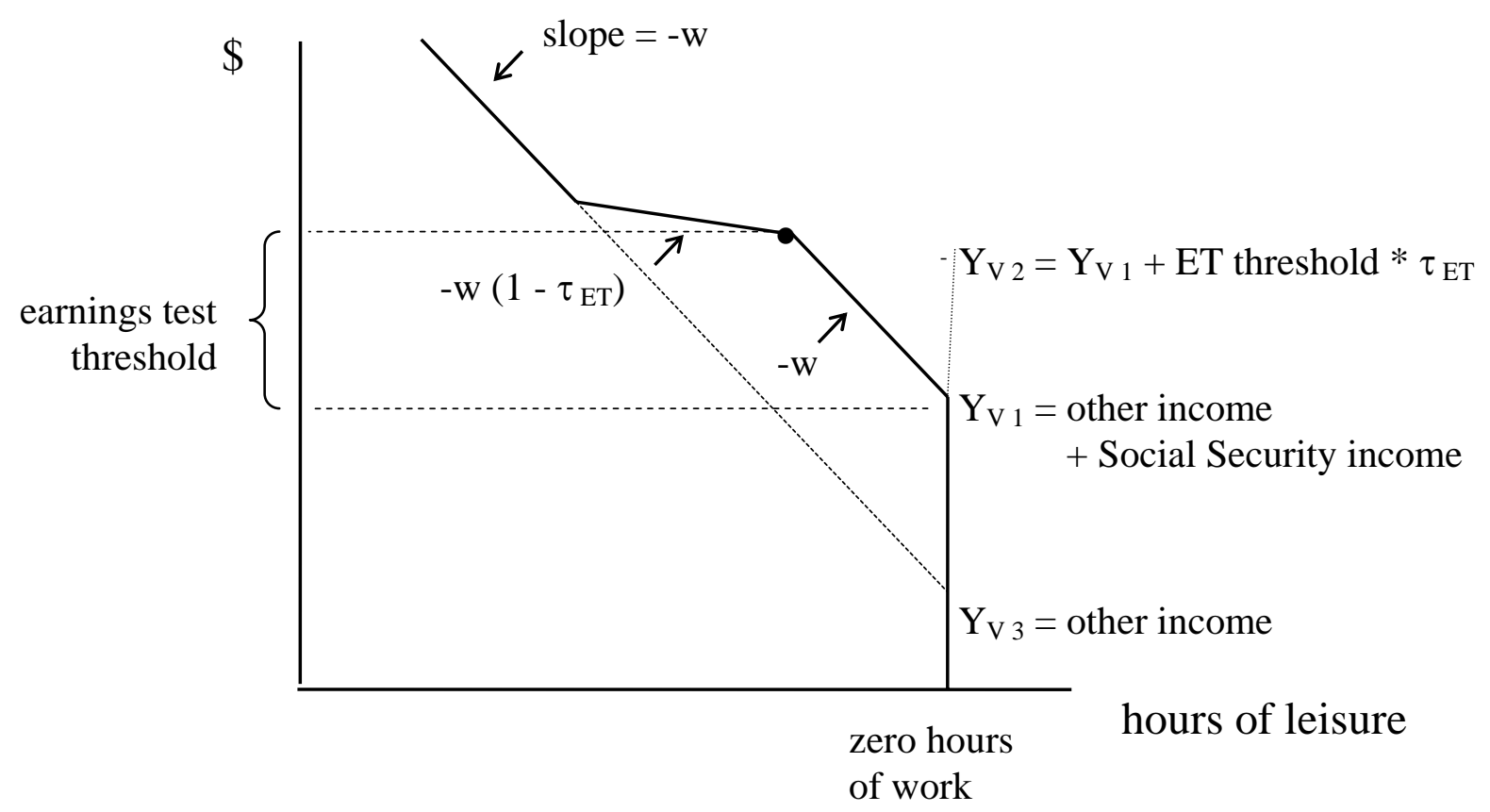



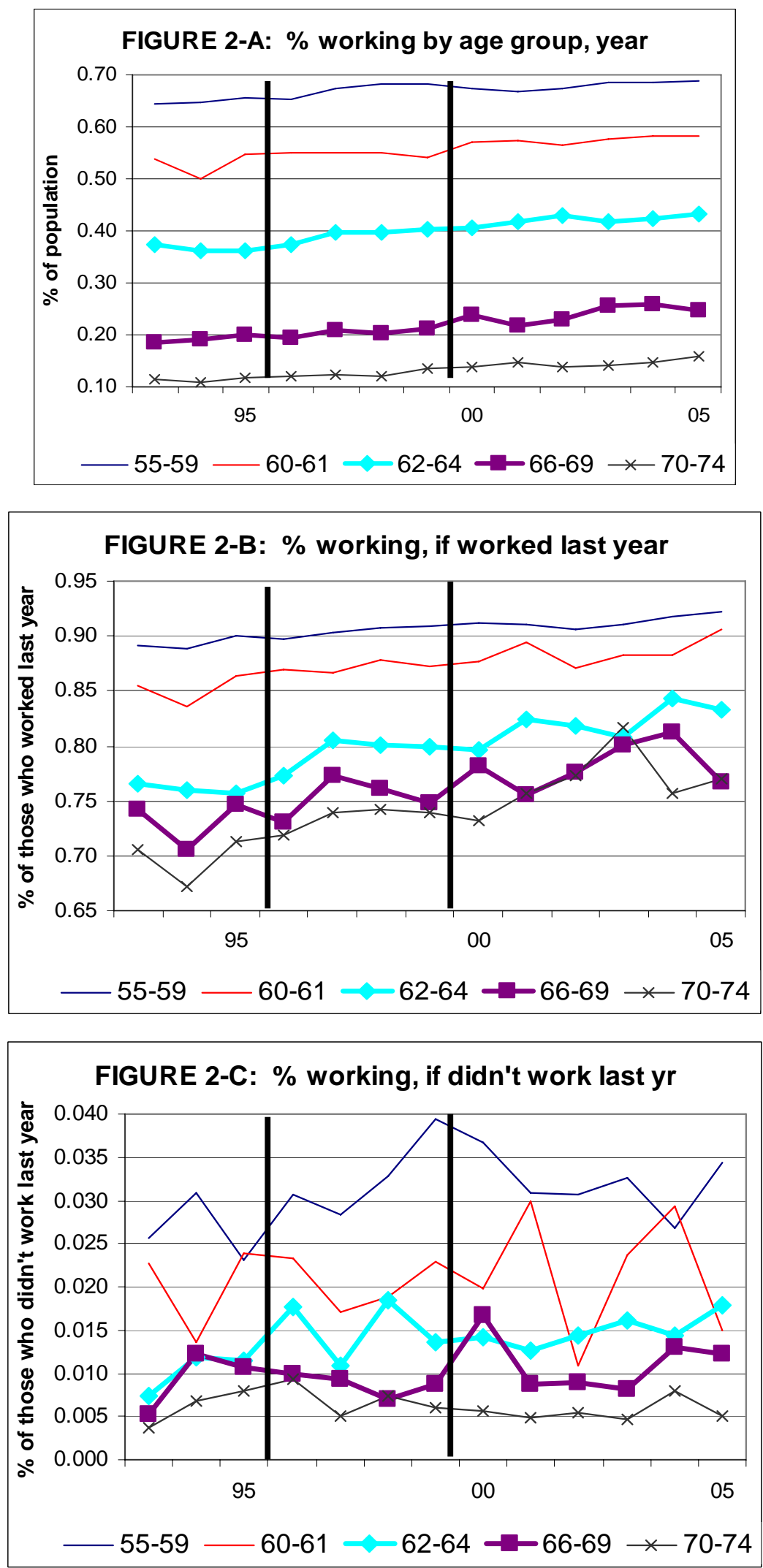

Notes: Data from March Current Population Surveys of 1992-2005. Additional details are provided in the text. 

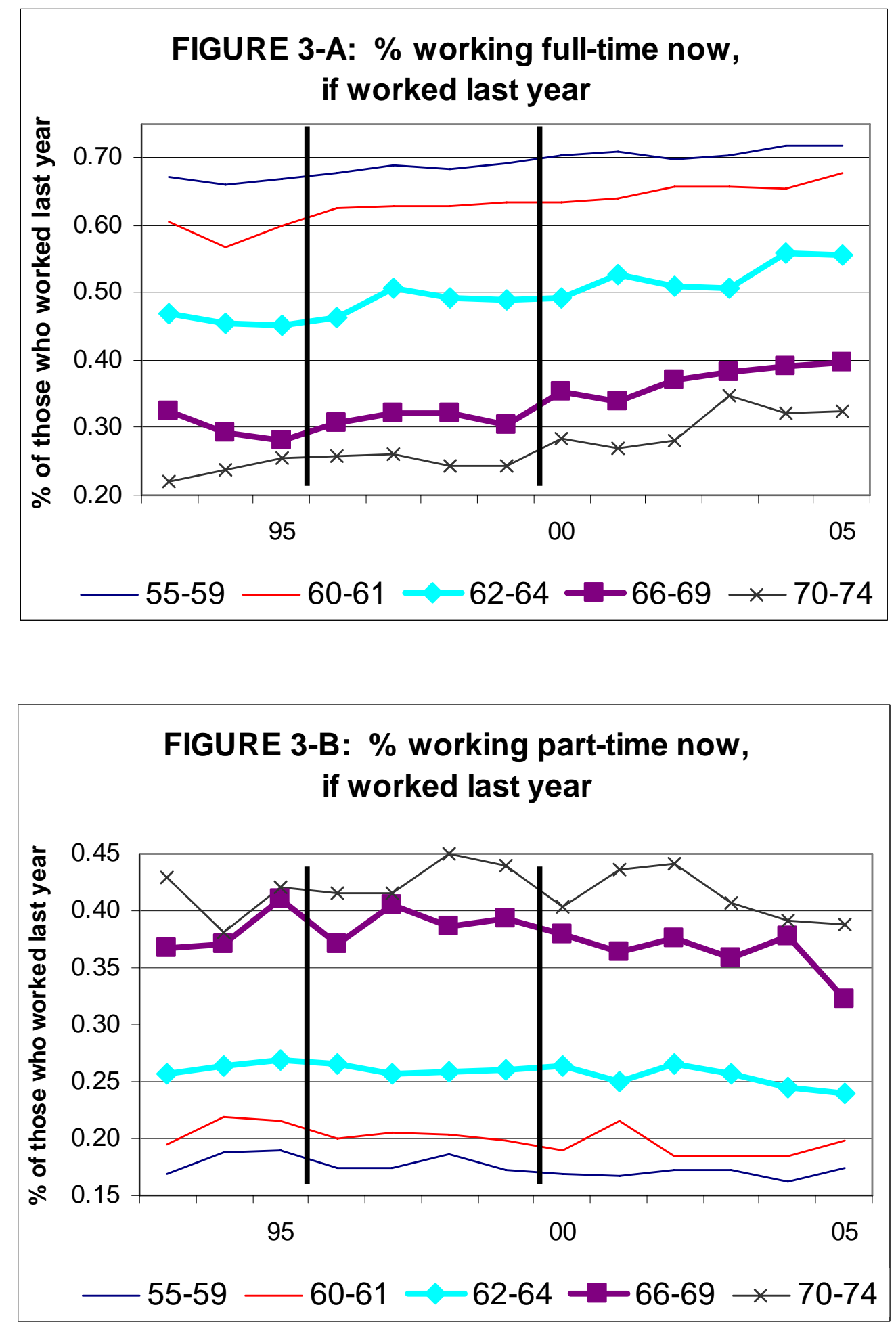

Notes: Data from March Current Population Surveys of 1992-2005. Additional details are provided in the text. 

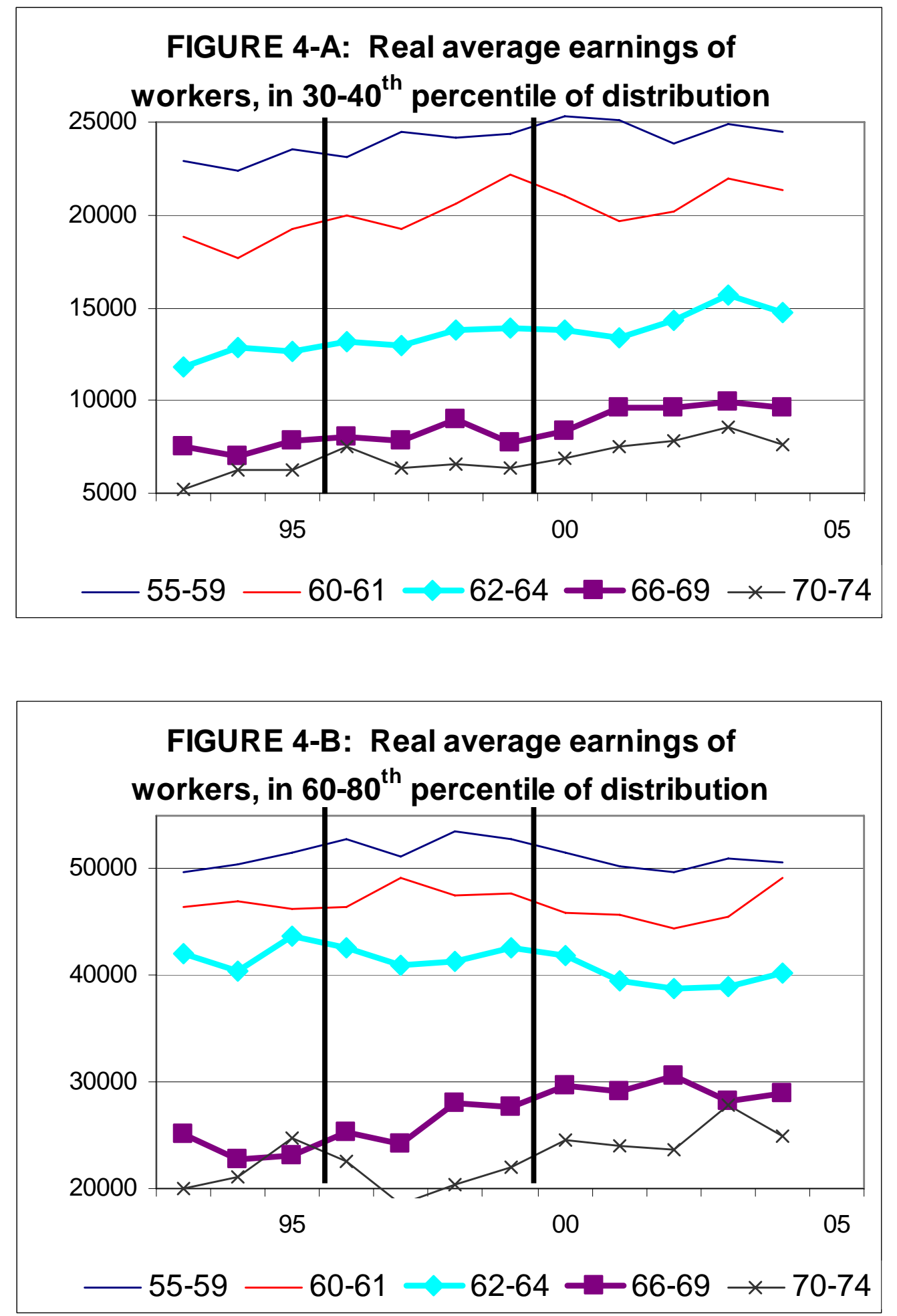

Notes: Data from March Current Population Surveys of 1992-2005. Additional details are provided in the text. 


\section{RECENT WORKING PAPERS FROM THE \\ CENTER FOR RETIREMENT RESEARCH AT BOSTON COLLEGE}

Annuitized Wealth and Consumption at Older Ages

Barbara A. Butrica and Gordon B.T. Mermin, December 2006

Risk and Reward of International Investing for U.S. Retirement Savers:

Historical Evidence

Gary Burtless, December 2006

State Age Protection Laws and the Age Discrimination in Employment Act Joanna Lahey, November 2006

Age, Women, and Hiring: An Experimental Study

Joanna Lahey, November 2006

Optimal Retirement Asset Decumulation Strategies: The Impact of Housing Wealth Anthony Webb, Robert Triest, and Wei Sun, November 2006

The Impact of Aggregate Mortality Rise on Defined Benefit Pension Plans Irena Dushi, Leora Friedberg, and Anthony Webb, November 2006

Health Care Costs, Taxes, and the Retirement Decision: Conceptual Issues and Illustrative Simulations

Rudolph G. Penner and Richard W. Johnson, November 2006

Why Do Boomers Plan to Work So Long?

Gordon B.T. Mermin, Richard W. Johnson, and Dan Murphy, November 2006

Job Tenure and Pension Coverage

Alicia H. Munnell, Kelly Haverstick, and Geoffrey Sanzenbacher, October 2006

Has the Displacement of Older Workers Increased?

Alicia H. Munnell, Steven Sass, Mauricio Soto, and Natalia Zhivan, September 2006

No Place Like Home: Older Adults and their Housing

Timothy Smeeding, Barbara Boyle Torrey, Jonathan Fisher, David S. Johnson, and Joseph Marchand, August 2006

All working papers are available on the Center for Retirement Research website (http://www.bc.edu/crr) and can be requested by e-mail (crr@bc.edu) or phone (617-552-1762). 